\title{
The Work of Sales Representatives in the Context of Interactions and Work with Emotions
}

\author{
Beata Pawłowska \\ University of Lodz, Poland
}

DOI: http://dx.doi.org/10.18778/1733-8077.16.4.05

\section{Keywords:}

Job; Profession; Sales

Representative;

Emotional Labor;

Work with

Emotions; Managing

Emotions; Symbolic

Interactionism;

Unstructured

Interview;

Observation;

Sociology of

Emotions

\begin{abstract}
The article aims to present the interactional encounters undertaken within their professional context by the studied group of Polish sales representatives concerning their emotions and emotional work. It is an internally diverse group made of individuals skillful in managing their emotions, as well as the ones of others. Additionally, the professional group at hand is purposefully trained to acquire skills in the area of managing emotions. The concepts of Everett Hughes (1958) concerning work, Arlie Hochschild (1983) in the context of emotional labor, Anselm Strauss (1993) pointing to the coexistence of emotions and action, and Robert Prus (1997) on the contextual nature of social life are the theoretical underpinning of the article. They all derive from the interpretative paradigm and fit into the theoretical premises of symbolic interactionism, assuming the constant construction of social reality as a result of interactions undertaken by social actors (see: Blumer 2007). It is the nature of their interactions with customers, colleagues, and direct and indirect superiors that determines the specificity of a sales representative's work situation. The analyses presented in the article are based on qualitative research using unstructured interviews, conversational interviews, and observations.
\end{abstract}

Beata Pawłowska is an Associate Professor of humanities and science in the field of sociology. A sociology and psychology graduate (specializing in Human Resources Management [HRM]). She works at the Department of Sociology of Organization and Management, Institute of Sociology, Faculty of Economics and Sociology, University of Lodz. A researcher of organizational culture currently focused on emotional behavior(s) within the professional contexts. She is a member of many research teams and a post-graduate Lecturer in coaching, HRM, and public relations. She is the Head of postgraduate studies Effective Public Sector Manager. She is particularly interested in issues regarding emotions in the work environment, including the educational environment. She has authored several books, among others, Network marketing. Kulturowe i osobowościowe wyznaczniki uczestnictwa w Amway [Network Marketing. Cultural and Personality Determinants of Participation in Amway] (2011, Wydawnictwo Uniwersytetu Łódzkiego, Lodz, ISBN: 978-83-7525-600-0) and Emocje społeczne w pracy nauczyciela i przedstawiciela handlowego [Social Emotions in the Work of Teachers and Sales Representatives] (2013, Wydawnictwo Uniwersytetu Łódzkiego, Lodz, ISBN: 978-837525-312-2).

email address: beata.pawlowska@uni.lodz.pl 


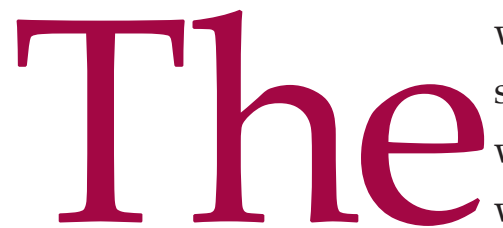

work of a sales representative consists of working with people, who are the main factor influencing the way they take actions related to working with emotions. Interactions with clients, co-workers, and direct and indirect superiors are a source of motivation to work, job satisfaction, and, most importantly in the context of this article, working with emotions, defined by Arlie Russell Hochschild (1983; 2009) as emotional labor, emotional work, or work on emotions.

The theoretical basis of the article are the concepts of Everett Hughes (1958) concerning work, Arlie Hochschild (1983) in the context of emotional labor, Anselm Strauss (1993) pointing to the coexistence of emotions and actions, and Robert Prus (1997) on the contextual nature of social life. They all derive from the interpretative paradigm and fit in with the theoretical assumptions of symbolic interactionism, assuming the constant construction of social reality as a result of interactions undertaken by social actors (see: Blumer 2007). All the considerations presented here refer to the situation of Polish sales representatives and are thus set in the Polish social, cultural, economic, and legal contexts.

The specificity of a sales representative's work is determined by several main factors. Firstly, these are the above-mentioned interactions with colleagues, superiors, and clients. Secondly, it is their identification with a company, in the case of which, analogically to the emotional work they undertake, two levels can be distinguished, that is, surface and deep identification. Thirdly, it is the scope of duties, which includes customer service, collecting orders and sales control, keeping contracts on time, promoting and presenting goods, upholding the company's image, and monitoring competition. Additionally, the specificity of a sales representative's work is determined by training and the company's motivation policy. Sales representatives are a group of employees most often participating in various types of training (cf. Mayo 2002). Since their activities directly translate into the profit of a given company and are easily measurable, the employer needs to create optimal conditions for the most effective sale of the company's products (cf. Prus 1994; Schweingruber and Berns 2003). By participating in training, sales representatives not only gain knowledge about the products offered, but also improve sales techniques, learn negotiations, manipulation techniques, the ability to establish and maintain relationships with the client, and manage their own and client's emotions (see: Pawłowska 2013). They develop soft skills (e.g., communication skills), as well as linguistic and technical skills (e.g., using computer programs, driving a car in difficult conditions). Sales representatives are also a group of employees to which separate incentive systems are applied, including salary scales. The sales representative's salary consists of a fixed salary, as well as a commission and a bonus. The salary of a sales department employee de facto depends on the amount of work and the number of products sold. Apart from financial incentives, such as, inter alia, remuneration in a mixed system based on commissions, bonuses, vouchers, passes, trips, and non-financial ones, such as diplomas, cups, company gadgets, non-material motivators, such as verbal praise and competition, are also important (see: Pawłowska 2013).

The aim of the article is to present the professional interactions undertaken by sales representatives in relation to the emotions they experience and how they work with them. It should be noted that the presented perspective does not apply to sales tech- 
niques and practices of buyers (see: Prus 1989). The specificity of the work of a sales representative concerning its selected aspects has been shown from the perspective of the employee.

\section{Research Methodology}

The issues touched upon in the article are the results of research conducted in the environment of sales representatives. It is an internally diverse group that is an interesting example of managing one's emotions and the emotions of other people, to which they are trained. Also, this group is highly diversified in terms of demographic characteristics. This occupational category includes both men and women, very young people and those in the pre-retirement age (although the majority are people under 40), people with general or technical secondary education (e.g., sale of tools, central heating stoves), as well as those with higher education (e.g., doctors, pharmacists, engineers, humanists), including people who completed postgraduate studies, for example, in the field of MBA. They are representatives of various professional fields working for both large international concerns and small local companies and organizations. They occupy various levels in the corporate hierarchy (from rank-and-file sales representatives, merchandisers, to commercial directors who are members of the board). Therefore, the category of sales representatives includes all people employed in organizations and institutions as a sales, pharmaceutical, or medical representative, who perform work consisting of daily contact with an individual, wholesale, or institutional customer (see: Pawłowska 2013; cf. Kempny 2008).

It was a qualitative research using unstructured interviews (see: Lutyński 1968; 1994; Przybyłowska 1978; Konecki 2000; Kvale 2004; Silverman 2007;
Pawłowska 2013), conversational interviews (see: Konecki 2000), and observations (see: Schwartz and Schwartz 1955; Hammersley and Atkinson 2000; Konecki 2000; Prus and Grills 2003). Additionally, I conducted a series of informal conversations with representatives of the described professional group. I also analyzed existing materials, such as questionnaires for the evaluation of sales representatives' work, work regulations, job descriptions, scopes of duties, responsibilities and powers, training agendas, training reports, law regulations, and others.

The studies were inductive using triangulation, which allows the researcher to distance themselves from the analyzed data (Hammersley and Atkinson 2000). The study used data triangulation, methodological triangulation, and theoretical triangulation (see: Denzin 1978; Konecki 2000:86). Qualitative research allowed for the collection of empirical data in the natural environment, everyday and basic context in which the analyzed phenomena and processes took place (see: Prus 1997:192; Deegan 2001; Hammersley and Atkinson 2007; Kostera 2003:12; 2011:9; 2012:73).

The main research technique was in-depth unstructured interviews (63 interviews). The interviews concerned the nature of the work of the sales representatives and the description of various situations related to their contacts (interactions) with customers, colleagues, and superiors. The representatives talked about their working day, emotions accompanying the work, and activities undertaken as part of their official duties. In the interviews, I tried to draw attention to the essential elements of the work of a sales representative, with particular emphasis on "easy" and "difficult," pleasant and unpleasant, positive and negative situations, as seen by them. 
The average duration of an interview was 52 minutes, but some interviews lasted much longer (over 2 hours). During the research, some of the interlocutors were returned to and interviewed again. Usually, such situations took place after the researcher got to know the informant more closely, and it happened that the subsequent interview took place at the request of the latter. It allowed, inter alia, the contextualization of the data obtained in the first interview and to confront the observed data with the information provided by the respondents (see: Silverman 2007; Becker and Greer 1960). During the interviews, the informants were open-minded and rather willing to talk about their work and the emotions that accompanied it. The interviews were conducted in places and situations convenient for the informants. Most often it was the interviewee's home, researcher's house, café, a room at the respondent's workplace, or the respondent's company car. All interviews were audio-recorded, transcribed, coded, and analyzed based on the principles of grounded theory methodology. The following grounded theory methodology procedures were used: substantive coding, including open and selective coding, theoretical coding, memo-writing, diagramming. Based on the constant comparative method, categories, their proprieties, and dimensions have been reconstructed, including experiencing the emotion of pride and work with emotions.

As mentioned before, the data from the interviews were supplemented with the information collected in the course of the observations and the existing materials made available. I conducted 1) 4 full-day participant observations during one-day training courses for sales representatives (introductory training and training in selling, called by the informants "knowledge" training [in vivo code]); 2) 2 full-day participant observations during 2 two-day training of sales representatives (integration training and sales summarizing training);3) 4 full-day quasi-participant observations during one-day and two-day training of sales representatives conducted, among others, by me (training in the so-called soft skills and sales techniques); 4) 4 overt observations during full-day training courses for sales representatives (various types of training in which I was a passive observer); 5) 12 overt observations during organizational meetings of sales representatives; 6) 5 overt observations of a sales representative working day (I travelled with a sales representative, observing the activities undertaken by them during the entire working day). Two such observations were carried out during the so-called "coaching." In the car, apart from the sales representative and myself, there was their direct supervisor, responsible for observing the activities of the employee, providing tips for better and more effective work.

To conduct some of the above observations, I took on the role of a sales representative. With the approval of the company's management, I participated in initial training and later in training as a sales representative. My researcher's identity was not known to other trainees, including regional sales representatives from other regions. Such a type of observation can be described as a semi-overt observation because the identity of the researcher was known only to some training participants (cf. Pawłowska 2013). The observation of training in which I acted as a lecturer (trainer) was possible since I was not the only trainer. Both during breaks

\footnotetext{
${ }^{1}$ I used the phrase "the so-called coaching" since this activity was thusly called by those under study (both the employee and his supervisor, who also acted as a coach). In my opinion, it was not a coaching session, but an observation of the sales representative's work by their supervisor combined with an assessment of the work and an indication of "right" and "wrong" actions taken by the employee.
} 
in my training and during training in which I participated as a participant or observer, as well as during the observation of the sales representative's working day, I conducted informal conversations with the respondents.

By conducting my observations, I wanted to participate in all major events taking place in the work of a sales representative, wishing to understand their perspective and to study phenomena that are little known or atypical areas of better-known phenomena (Deegan 2001; Kostera 2012:73; also: Kostera 2003:12; 2011:9). One of the advantages of observation is the ability of the researcher to grasp the context of certain phenomena or interactional episodes, and thus-to reconstruct the elements of the analyzed processes, which would not be possible if the study were conducted using other research techniques and tools (see: Adler and Adler 1987; Konecki 2000; Wojciechowska 2018). For this purpose, an observation diary was kept, which, like David Silverman (2007) observes, provides space to distinguish emic from the etic analysis. After each day of observation, I wrote an observation report and, if possible, took notes during the observation.

\section{Work in the Lens of Symbolic Interactionism}

The purpose of the following is not a definitional overview, but to indicate the understanding of the concept of work from a sociological perspective, with particular emphasis on the interpretative paradigm. Work, in the sociological sense, is a source of wealth. But, at the same time, it has a much more vital meaning because it "builds" one (Dzięcielska-Machnikowska 1990:226). Work is "a kind of human activity, carried out mainly in the institutionalized frames because of the division of labor and its specialization" (Kulpińska 1986:9). As Jan Szczepański (1961:171) wrote, work is "any deliberate activity leading to the satisfaction of any human needs, having social significance, providing individuals or groups that perform it with a specific position in society." This definition highlights several aspects of the job.

First, work is a conscious and purposeful human activity. It may be dictated by the free choice of the individual or by compulsion (see: Lis 1982:9). However, what appears to be one's freedom can sometimes be seen in terms of a constraint; and vice versa- a constraint can become one's free choice. This phenomenon is referred to as "work fanaticism" (see: Dzięcielska-Machnikowska 1990:228). It seems that work itself is a compulsion. One's urge to meet the needs requires work, which is related to earning money. Money enables the fulfillment of the individual's needs. Thus, freedom of choice is not about whether to do work or not, but what work to do. But, here, too, the choice may be significantly limited. What we do is influenced not only by our education, our abilities, and predispositions but also by the economic situation of the state, including access to work.

Secondly, work is a social activity, which means that the way it is carried out affects the aspirations, attitudes, behaviors, and interests of other people or groups. Working in this sense is one of the most important elements of social bonds. It shapes coexistence with other people. The social nature of work is manifested in the fact that the work performed by an individual is always related to the work of others. At work, a person confronts their views with the perceptions and attitudes of other people, which leads to the development of attitudes that are socially expected and desirable. 
Third, work determines the social position of an individual. It is an indicator of their status and social role. Thus, it will affect the way emotions arise and how we manage them.

Fourth, work is done to meet needs, but such needs are determined by the structure and culture of the group to which the individual belongs. The culture of a given community and the group of employees shape not only the attitude of employees towards work but also the way it is performed. Thus, work has a cultural dimension (cf. Fukuyama 1997).

Finally, in the approach to work that is of my utmost interest, the fact that work influences the self-esteem of an individual is of great importance. Self-evaluation is associated with the emergence of different emotions, but it can also be the result of the arousal of different emotions. In the course of work, each individual strives to achieve success, which conditions the emergence of the emotions of pride and avoiding failure, which, in turn, contributes to avoiding the emotions of shame. "Man's work is one of the things by which he is judged, and certainly one of the most significant things by which he is judged" (Hughes 1958:42). It can be stated that professional activities, the course of a professional career, interactions with colleagues, and superiors will have a huge impact on the development of one's self. Through work, and thus the profession, a person evaluates oneself, develops their opinions about oneself, assigns value to oneself, and builds their groups of reference and identification (see: Hughes 1958; Konecki 1988). Such an understanding of work is dynamic, and the subjective feelings of individuals are central here. The aspects that contribute to the emergence of various dependencies between individuals are important. The existence of work is not possible without the social environment and the interactions that an individual undertakes. In the course of work, people constantly communicate, be it ordering to do something, informing, persuading, or negotiating. "It is impossible to work without the coordination of activities on the part of those who define it, perform it, provide the necessary work equipment, and control, and repair this equipment. Work is impossible without the audience, who can actively cooperate, and even their presence alone can influence the work process" (Konecki 1988:234).

In general, I will understand work as an organized activity of many entities, that is, individuals that adapt and interact with each other. Actions and maintenance of all social relations are possible due to the process of mutual interactions. This process of mutual communication clearly influences the emergence of specific emotions. Emotions always arise from the interaction. According to Strauss, they are part of the action and are never separate from it. Separating emotions from action causes their reification (Strauss 1993:31-32). These interactions can take place on many levels. We can communicate with other individuals, groups (of different sizes), but also with ourselves. In the empirical section, the analysis of the work situation will come down to a description of interactions in a group of sales representatives and to capturing how the group and individuals influence the formation and management of an employee's emotions.

Work in the sense proposed here is not only an interactional process, the production of external goods, but also a process taking place within the employee. A process that allows one to manage their own emotions, but also other people's emotions. This process of work taking place within an individual has been called working with emotions. 


\section{Working with Emotions}

In my opinion, terms working with emotions, work on emotions, or emotional labor can be used interchangeably. In doing emotional work, the individual is doing work with emotions. Consciously or not, it transforms emerging emotions. It evokes specific and desired emotions in a given situation, but can also manipulate the recipient's emotions. Having a whole range of available emotions, one chooses the specific ones that, in their opinion, will allow one to achieve the intended goal. So emotional work is working with emotions. It is especially visible during actions taken by sales representatives. From the emotions available to them, they choose those that allow for effective sales and the continuity of positive interactions with customers.

In the literature on the subject, there are two general approaches to investigate the topic at hand (Meanwell, Wolfe, and Hallet 2008; Wharton 2009; Rogalin and Hirshfield 2013). The first approach explored emotional labor from the angle of emotional management and expressed emotions (Kanter 1977; Hochschild 1983; 2009; Smith and Kleinman 1989; Sutton 1991; Pierce 1999; Raz 2003). These authors focused on the understanding of emotional labor in terms of individual management of emotions (or how a person controls their emotions in the workplace). The second approach highlighted interactions that occur in the service occupations in which emotional labor is most common (Hochschild 1983; 2009; Rafaeli and Sutton 1990; Williams 2006). In other words, this literature tends to emphasize interpersonal emotion management or how a person attempts to control other people's emotions (Rogalin and Hirshfield 2013).
When writing about working with emotions, emotional labor, emotional work, or working on emotions in the context of the profession of a sales representative, one should, first of all, refer to the concept of Arlie Hochschild. In her understanding, emotion is a biologically defined sense. "It is how we know our relationship with the world and thus it plays a key role in the survival of human beings in group life" (Hochschild 2009:238). Expressing the right emotion serves not only to adjust to social circumstances but also to change our emotional state. Emotions, in Hochschild's opinion, play a signaling function, they show us our position in the world and define relationships towards others and towards our goals, motives, and interests. "Emotional experience is an amalgamation of how we feel, how we would like to feel, how we classify feelings, and how we express them" (Kemper 2008:380). The way we feel is determined by our assessment of the situation. In turn, assessment of the situation is influenced by structural elements such as social class, occupation, gender, age, and cultural aspects such as "rules of feeling" and "rules of expression." It is all done to comply with specific standards of a given community, including the organization. Sales representatives, just like the professional groups surveyed by Hochschild (flight attendants and debt collectors), actively manage their feelings to adapt their identities to the requirements of the professions in the area of contact with customers. They do emotional labor managing their emotions to be good workers. Emotional work is defined here as the ability to modify or change emotions as required by the employer. Thanks to emotional work, an individual reveals the appropriate (desired in a given situation) emotions. When working with emotions, we use a number of techniques to facilitate feeling and expressing appropriate behaviors. And so we 
do: 1) work on the body, changing our physiological reactions to a given situation; 2) superficial actions, that is, we use external gestures leading to the feeling of emotions signaled in the expressed gestures; 3) deep actions to evoke specific feelings that, in the perception of an individual, should be shown in a given situation; 4) cognitive work through which a person evokes thoughts and ideas associated with a certain emotion to emerge (see: Hochschild 1983; 2009).

Moreover, emotional work can take two forms: surface acting and deep acting. Surface emotional labor involves changing emotional expression (external action) without changing the emotion felt (e.g., an employee smiles at a client, co-worker, or boss, although they experience emotions other than content or joy). Although the emotions of the employee do not change, their expression is consistent with the accepted standards of the work. The employee "puts on a mask" when interacting with their clients (Springer and Oleksa 2017:607). Deep action, on the other hand, occurs when an individual tries to change a feeling by changing its determinants, such as the mental construct or evaluation that gave rise to the feeling, and basic physiological factors such as muscle tone and heart rate (Kemper 2005:380; cf. Hochschild 1983; 2009). Deep emotional labor is about changing the emotions you feel by adopting a specific way of thinking about a situation. It is an internal work, where the individual eventually feels the desired emotions and expresses them. The expression is natural. It is not a mask put on for the needs of a given interaction, but an internally felt emotional state. The employee modifies their internal experiences adequately to the desired situation. By performing deep work, they evoke emotions that are beneficial for the goals of the organization in which they work (Springer and Oleksa 2017:607).
Those two forms of emotional work differ from each other in terms of the activation of different emotional regulation strategies (see: Gross 1998; Grandey 2000). In the case of deep work, the employee takes regulatory actions that anticipate the emergence of emotions, while in the case of surface work, we deal with correcting emotions that have already arisen. It is a kind of pretending emotions and hiding real feelings (cf. Lee and Brotheridge 2011). Sales representatives who enter into short-term relationships with the client will more often use surface emotional work (see: Springer and Oleksa 2017), expressing appropriate (desired in a sales situation) emotions and suppressing their actual ones (Szczygieł et al, 2009).

Summing up, it can be stated that, according to Hochschild, in various organizations or other workplaces, we deal with certain rules of the system, which is a component of people's emotional labor (Hochschild 2009:2). And the employee's emotional labor consists of arousing or suppressing certain emotions they feel in accordance with the mission and goal of the organization (Hochschild 2009:5-89). Managing emotions means actively attempting to change a pre-existing emotional state (Hochschild 2009:238). Performing emotional labor, although desirable by the employer, can cause negative outcomes for employees (see: Hochschild 1983; 2009; Grandey 2000; Brotheridge and Grandey 2002; Johnson and Spector 2007; Szczygieł et al. 2009).

\section{The Elements of Sales Representatives' Work in the Context of Working with Emotions}

Looking at the work of a sales representative, it is easy to notice that it is a job in which interactions with other people are of importance. It is the nature 
of the interactions with customers, co-workers, and direct and indirect superiors that determines the specificity of the sales representative's work situation. In their statements, the participants emphasize all activities that build and maintain the relationships with the clients. Contact with other people is also an important factor in choosing this profession and affects the dynamics of work. By interacting with the client, the sales representative takes the appropriate role and controls their emotions. The emotional work that takes place when interacting with the client is conscious and controlled. Sales representatives learn the emotional manipulation strategy during a series of training, which is one of the distinguishing features of their work. Below, I will refer to selected elements determining the specificity of a sales representative's work. In the opinion of the interviewees, working with emotions is mainly influenced by working conditions and interactions they undertake. Work is a process. It is considered in relation to social life as a constantly ongoing process of "becoming" in the sense of the successive shaping and transforming of the subjective definition of oneself and society (Konecki 1988:226). The work of a sales representative requires cooperation. This means that in the work process it is important to coordinate, manage, and cooperate even with individuals dispersed in time and space in order to meet the group and individual goals. Rules of operation and work contexts are established. Actions are taken, including sequences of actions (cf. articulation work), that require adjustment to the organizational reality to achieve the desired result (see: Strauss 1988).

\section{Working Conditions}

One of the main reasons behind undertaking the job at hand is salary.
Well, of course, money is important and necessary. After all, we all work for money. I'm on commission, I get a kind of bonus from the activity and quarterly sales growth. If the company exceeds the assumed profit in the financial year, both I and all marketing receive a bonus. Anyway, it is one of the terms of the contract, a great privilege in these times. [man, 38-year-old, sales representative, electronics industry]

Salary is a classic motivator that encourages people to work more effectively and efficiently and to climb the ladder of career advancement. The research of Kopertyńska confirms the results of my research. In the group of 60 salespeople surveyed by Kopertyńska, $74 \%$ of respondents considered wages to be the most motivating factor. The respondents equally recognized wage components such as base salary, team bonus, and commission bonus as the most important motivators (Kopertyńska 2009:75-76). It should be noted here that the possibility of obtaining high remuneration in Polish reality is one of the main reasons for taking up employment as a pharmaceutical or medical representative by people graduating from medical studies, including doctors and pharmacists. The salaries of doctors in Poland are often much lower than the salaries of medical sales representatives.

I know the sales representatives earn quite a lot, especially pharmaceuticals like myself [laughs], but we work hard. I have to work to keep the level. I got used to and probably my wife also got used to living on a certain level. It would be hard to give it up now and return to the learned profession. [man, 44-year-old, sales representative]

Finances and other material resources (e.g., a company car, laptops, health and pension insurance, material awards, business trips, holidays) offered 
by organizations employing sales representatives are factors not only encouraging to work, but also maintaining or breaking the bond with the organization.

This type of job allows me to earn more money, and it gives me satisfaction and willingness to work here. [woman, 37-year-old, sales representative, medical industry]

The informants linked the amount of remuneration with the prestige resulting from work in a specific industry or organization:

very nice working conditions, because those were the times, it was the 2000s...you can say that uhm if someone worked in the alcohol industry in those times, you can say the first league, the best, the best money. You drove, you drove, so to speak, the best company cars and, in general, the working conditions were really uhm definitely the best. [man, 42-year-old, sales representative, spirits industry]

Identification with the workplace, the organization for which the sales representative works, is visible on two levels. The first is external (surface) identification, which is expressed primarily through the external appearance of the employee and is often an element imposed by the employer. Sales representatives usually receive guidelines on how to look. The standards of external appearance often apply to clothing, makeup, hairstyles, and jewelry. An item of clothing is a type of mask worn to perform a given job. By putting on the "business" attire, the employee takes a professional role that determines the ways of managing emotions and influences the emotions arising in interactions. The uniform even determines the necessity to perform surface emotional work. Acting as a sales representative, the employee puts on the official outfit along with patterns of desired gestures and behaviors.

The second level is internal (deep) identification, which requires work on oneself. It is expressed, among other things, in identifying with the company for which the sales representative works. When an employee becomes a part of the company, when they internalize its values, norms, adopt an organizational culture, then we have to do with a strong identification. Deep identification of sales representatives with the company is reflected, among others, in recommending the company's products to friends and acquaintances, as well as in using those products on their own. The sales representative considers the products of the company for which they work to be good and recommendable. This happens even if they did not have a positive opinion about the products sold before and their attitude towards them was negative. According to the thesis that you can only sell what you believe in (cf. Schweingruber and Berns 2003), sales representatives work on changing their attitudes. The bigger the change, the stronger the identification with the company. Identification also manifests itself in the difficulties with separating work from private life. It is particularly visible in the group of sales representatives dealing with the sale of financial products such as insurance and policies. The interlocutors indicate the emergence of certain habits that, acquired at work, affect the nature of social contacts outside work. It happens unconsciously, which indicates a strong internalization of organizational values and norms and deep emotional work. The work of a sales representative for financial reasons, but also certain freedom as to working time, implementation of tasks and the possibility of self-determination of individual, priority goals, becomes a highly addictive activity, “Today, I cannot imagine myself in a different sys- 
tem, this job is becoming a habit" (male, 33-year-old, sales representative).

A change of attitudes also takes place concerning emotions felt and desired by the employer. The rationalizations made by the informants prove the strong identification and the emotional work performed. An example is offered by an interviewee working in a company perceived negatively on the labor market. It is a kind of justification for working for an organization that does not have a good reputation on the market.

Yes. I'm not ashamed of the place, I'm not ashamed of the company where I work. Uh... I don't know. Uhm... It's not a problem for me whether to tell someone where I work or to think badly about this company. If I hear some bad opinions among, I don't know, the market about this company, I can say I'm also struggling. Because, I don't know, I think it should be done. Besides, this is my employer. [woman, 28-year-old, sales representative]

The informant makes a rationalization, which can be described after Adie Nelson and Ronald Lambert (2001) as an emotional change. ${ }^{2}$ She proudly emphasizes her identification with the company. Loyalty is a socially perceived positive trait. Therefore, although the company has a bad image, its employee does not show the emotions of shame. Not showing shame does not mean that the emotion of shame has not arisen (see: Scheff 1988; 1990; 2000; 2003). Due to

${ }^{2}$ Adie Nelson and Ronald Lambert distinguished three neutralization techniques: emotional obfuscation, changing places, and defining truth. Emotional obfuscation is a technique that consists of seeking justification by referring to the emotional reaction of the environment. The authors argue that neutralization techniques can help "save face" not only in the immediate context of a specific act (see: Sykes and Matza 1979:498) but also when no guilt or shame is felt. They allow us to avoid internal contradictions (see: Nelson and Lambert 2001:84-87). the poor social reception of the workplace, the interlocutor has developed a rationalization that protects against negative feelings. This is one way to deal with the emotion of shame. It is a defense against social withdrawal and breaking social ties. Another example of rationalization is provided in the quote below which simultaneously shows the feeling of an emotional bond with the company.

And I felt connected with that company, and I felt connected with the uhm brand, uhm, and I wasn't ashamed of any of those... I mean, I felt emotionally connected. I believed in what I was doing, I believed in those products, I believed in those people, and so on. [woman, 32-year-old, sales representative]

The bond with the organization is also maintained as a result of the emergence of the emotions of pride (see: Shott 1979; Goleman 1997; Williams and DeSteno 2008; Pawłowska 2020). In this case, of pride resulting from belonging to an organization and professional group:

I believe we are number one. And, and our facilities also prove it, that is, I feel good being a representative of company X...in general, I just feel good in my skin being in this company. [woman, 26-year-old, sales representative, office supplies]

Strong identification is visible in statements such as: we are one big family. [woman, 30-year-old, sales representative]

we are here to be successful as a company. [man, 34-year-old, sales representative]

I like my job as it is. Even while on vacation, I think about my clients. [man, 29-year-old, sales representative] 
Deep identification with the organization results from working with emotions, including the conversion of negative emotions into positive ones. The longer the work experience in the organization, the deeper the identification. The salary of a sales representative largely depends on the sales volume. Organizations often determine the level of sales, the performance of which determines employment. Unfortunately, such activities do not allow for building ties with the organization, as well as for deep emotional work. Sales representatives in such companies rely on the surface emotional work that they learn during the training offered to them. This arouses negative emotions among the informants, causing not only a lack of identification with the workplace, but also uncertainty, stress, and frustration.

I can never be sure of tomorrow. I don't know when I will be fired. [man, 31-year-old, sales representative, mobile telephone industry]

We are just bars. At the weekly, monthly, and quarterly meetings, the boss shows only the bars [charts with sales results], uhm, I am purple. As soon as the sale gets worse, you get a hard time. If it is good, you will not hear praise. So if it's bad, they'll throw you out. You work until your bar falls below the magic line. [woman, 27-year-old, sales representative, cosmetics company]

When sales representatives start working for the organization, they enter a new pattern of social relations. They conform to the rules and standards of a given company (surface identification). They internalize the values proclaimed by the employer. This process takes place in the sphere of the employee's unconscious actions. The sequential nature of the rituals, which are most often visible during training, causes the employee to become a person acting according to a specific pattern. This allows the company to manage not only the actions taken by the employee but also the emotions that arise during the interactions. Consequently, this leads to the creation of a feeling of strong identification of the employee with the organization, which, in turn, leads to the development of behaviors based on positive emotions, such as, for example, pride, complacency, satisfaction, or joy. The "learning" and application of a specific repertoire of emotional behaviors are sequential, unconscious, and relatively permanent.

\section{Interactions with Customers}

One of the main reasons for working as a sales representative, apart from the financial one, is the willingness to work with people and have contact with the client.

My motives were very simple-I just love working with and among people. In this job, I feel like the proverbial fish in the water. [woman, 42-year-old, sales representative]

Well, I mean, very nice, very nice job. Contact with people, first of all. [man, 32-year-old, sales representative, spirit industry]

The main responsibilities of sales representatives include customer service-collecting orders, field trips, contact with customers, researching customer needs, reporting customer visits, sales control, keeping contracts on time, presentation of new goods, and promotion. An important element of working with the client is solving the client's problems related to, inter alia, complaints, dissatisfaction with products, lack of skills in handling products. 
You know. Sometimes someone comes and your complaint is refused. In principle, it can be accepted, but the fewer complaints, the company has fewer problems...I always try to be loyal and reliably perform my duties. [woman, 36-year-old, sales representative]

You can notice that sales representatives use different ways of contacting customers. Some people prefer to be contacted by phone, which is usually sporadic. Direct contact is maintained with clients with whom the representative cooperates intensively. Most representatives find this type of contact better because it allows them to get closer to the client and get to know them better.

As I mentioned, what matters is the long-term nature of trade agreements. The most satisfied ones never leave me and I am still learning. In this job, you can still learn a lot about people, specific tastes, and expectations. [man, 42-year-old, sales representative]

Interestingly, there are also different ways of approaching customers depending on whether they are regular, new, or strategic clients. Strategic clients are often invited to participate in various corporate events, team-building trips, and training. An important task of a sales representative is to represent the company outside, for example, during fairs and other promotional events. The representative must also keep a close eye on the competition. The duties of the sales representative manager (e.g., regional sales manager) include coordination, supervision, and evaluation of employees' activities. The manager has to make sure that the representatives keep reports on activities and they have to carry out administrative and office work themselves. Managers say they are responsible for almost all sales in the company. The common task of managers and their representatives is to take care of the company's im- age and monitor competition. Another task of the manager is "coaching" and the control of suppliers' activities, including verification of promises made by contractors to sales representatives. Some regional sales managers, and even some representatives, are admitted to the recruitment processes. The studied professional group also has additional duties, such as participation in training, which may result from an employment contract.

The sales representative-customer relationship is an important factor influencing the emergence and management of emotions. Sales representatives declare having respect and sympathy towards their clients, and such interactions bring satisfaction. The informants talk about positive relations with customers, which may be the result of positively remembered transactions between the sales representative and "one's good customers," mutual satisfaction with the transaction between the interlocutor and the client, multiple contacts with certain clients, which increased the sales representative's turnover, an increase in the level of trust based on the economic exchange between clients and respondents. The respect mentioned in the narratives may result from the fact that sales representatives are obliged to declare an attitude of respect, and even esteem, towards their clients.

By internalizing the norms and values imposed by the employer, the informants manage their emotions in such a way as to feel the emotions desired in the customer-sales representative encounter. However, working longer for a given company or in the profession of a sales representative in general, they build lasting relationships with the client, turning superficial actions into deep ones. They start to like their customers, becoming patient and cheerful with them. The deep emotional work done is the source 
of friendship and even marriage. Some respondents pointed to the fact that their clients were treated as their mothers or grandmothers:

I really like Mrs. Jadzia. She is like my grandmother. Although she sometimes complains and does not always take what she ordered, changes orders, I know that I would let her do more. It doesn't make me angry, but it rather moves me. When she looks at me like that and says, "Sorry, I messed something up again," I only have warm feelings for her. [male, age 26, sales representative, food industry]

A true feeling of positive emotions is not an interactional game and is the evidence of deep work with emotions. Such actions, by the way, allow the sales representative to achieve their own professional goals, including achieving a certain profit.

Moreover, the interviewees indicate the types of clients and the strategies applied towards them. In the quote below, the interlocutor dichotomically divides clients into reticent versus talkative and nice versus unpleasant. At the same time, there is a kind of emotional self-defense that consists of preventing a negative emotion from occurring. The emotional veil makes the informant add that she has rather nice clients because she would not talk to others.

Customers are different, reticent, talkative, nice, unpleasant. Of course, we have to talk to everyone, but there are exceptions. After all, we do not have to endure rudeness and aggression, and such cases have happened. I have never encountered this personally. I tend to have nice clients. [woman, 26-year-old, sales representative]

A similar mechanism is seen in the next quote. Moreover, we can easily notice the emerging emo- tions of pride and satisfaction. The interlocutor emphasizes the fact that he has communication skills and knowledge of negotiation techniques.

Well, it is different. There are different buyers in Poland. Some can talk to a person, they are very positive. There are those from whom you have to draw every piece of information...Such an attitude that everything is always wrong. It takes so long to talk and convince. Fortunately, I have no problem with that. I can talk as needed. [man, 23-year-old, sales representative]

Sales representatives emphasize the positive attitude of customers and a pleasant atmosphere when making transactions and signing contracts. They indicate the direct and unofficial nature of the interaction.

In those stores where they know me, that's great. It's like, "Hello, Mr. [name], welcome" and we have a great chat. It's generally nice. [man, 25-year-old, sales representative]

I was called there Sunshine, Darling, Treasure, Love, everything that you can think of. I've even been called Pumpkin. In the beginning, it was a shock for me when I started cooperating with those stores. Now I'm used to it and I know it's what it is. I stopped being formal and instead of "Mrs." [the interlocutor shows the quotation marks], I just say "Hi Ladies." You can see that they want to talk this way, you have to adapt to make it nice and pleasant. [man, 23-year-old, sales representative]

The statement shows the need to work with emotions and to tune in to clients. The commercial exchange situation forces the sales representative to change the behavior so that they can adapt to a spe- 
cific customer. Changing behavior involves adapting a specific repertoire of gestures and emotions. It happens that during the whole working day, dealing with different clients, a sales representative uses different patterns of behavior and arouses different, specific emotions. Working with emotions is therefore continuous and guided by interactions with a given client.

When talking about customer relations, sales representatives refer to relationships with female customers. This is especially true in the food and cosmetics industries. It is more often noticeable among sales representatives selling directly to smaller stores, called by them "retail stores" (in vivo code). The interlocutors serving large-format stores or wholesalers do not indicate this type of dependence and do not divide customers by gender. This may be because more women work in retail, so those sales representatives have more contact with female customers. Managers of hypermarkets and wholesalers are more often men, perhaps hence the lack of a distinction between customers in terms of gender:

you have to talk to the employees of those stores. Most are women. I think the sales representative is a guy after all. It makes it a lot easier. Contact with a woman is always something like that, that's my impression. Most of the representatives, however, are men. And there is something about it, it's easier to be there. Mrs. Jadzia, Mrs. Asia, a tittle-tattle, and somehow it goes on. We'll have a good laugh together and it's fun. [man, 28-year-old, sales representative]

It's nice with women, but women are so much more focused on such things, such crap. And they are less able to generally say what there is in that store and what is missing...Our company cooperates with
S. Stores. There were already S. Stores during the Polish People's Republic. Well, this is a specific type of store. And this is my observation. Other staff works there. Women, because only women work there, I have not met any man working there, they are very specific. In all private stores, when I arrive, it's always "Mr." and there it's by your name. And I come, you know, I'm a young man, and it's different, too. For those women, it may be a sensation that a young boy is visiting. [man, 23-year-old, sales representative]

In dealing with the customer, especially in the case of sales representatives with a shorter experience, there is a surface emotional labor. Negative emotions do not appear in emotional expression. The informants emphasize that in contact with the client they cannot show anger, irritation, or impatience. They have to do emotional labor to maintain a good and lasting relationship with the client. Their remuneration and position in the organization depend on it. An emotional mask is put on that allows them to make a transaction.

I have already told him six times. I told him what it was about and he asks again. I cannot show irritation. I have to patiently answer this question again. [man, 36-year-old, sales representative]

The informants talk about "politically correct behavior" (in vivo code), which means that social bonds are durable. At the same time, it indicates taking actions related to surface emotional work.

Oh, a few have already upset me. This is life, it's hard to expect an ideal. I am learning to control my emotions. You have to control your emotions, it is useful in life-in fact, in any situation. This job taught me to be politically correct. [man, 42-year-old, sales representative] 
Sales representatives learn how to work with emotions that arouse during interaction with the client at training.

Yes, we have a lot of training...They mainly teach communication and negotiation, how to deal with a difficult client. After all, if the client is picky and whining, I won't tell him, "Get lost." Sometimes I want to shout or say something unpleasant, but I can't offend the client. The goal is long-term cooperation, and I know that. Therefore, in such situations, I learned to be silent, sometimes nodding, and then I calmly make the offer again. Yes, that's how it's done. [man, 32-yearold, sales representative]

\section{And also during their work.}

I used to worry when a client came and he immediately shouted and was dissatisfied. I was taking it personally. I was worried. Today it's different. Customers often come and say that they have been deceived because the price is different. Sometimes they challenge the company. I try not to listen to it. I explain the difference in the bill and that's it. It used to be that I felt like crying. I would go home and yell at my daughter. Today I'm calmer. I got used to it. The manager often says, "Don't worry. Do your thing." And so I do. [woman, 41-year-old, working in the customer service department of one of the hypermarkets]

The techniques of operation learned during the training are checked in direct interactional situations. This is when the actual work with emotions takes place.

I always try to focus on the feelings and needs of a specific person. I take into account the preferences of my clients-in fact, they should be satisfied!...I am learning to control my own emotions!...I ignore someone's ignorance and rudeness that overwhelm us. This is my emotional safety valve. [man, field sales representative]

Surface emotional labor, as a result of permanent and long-term interactions with the client, is transformed into deep emotional labor. The condition for such a change to occur is positive interactions with customers. Sales representatives gradually learn to control their emotions by actually feeling them.

\section{Interactions with Supervisors}

Another factor distinguishing the work of a sales representative in the context of their professional interactions is that the employer creates conditions of relative independence and freedom. It is also another factor influencing the employment of a sales representative.

The work of a sales representative is mainly fieldwork. Usually, the employee is not present in the office, but on their way, and during the working day they change their location several times; although there are also such working days when a sales representative performs some of their duties at the headquarters of the organization for which they work. Among the representatives with whom I have spoken, there were two types of work organization methods: 1) "own workshop"-the representative organizes their working time, arranges the day plan, sets the number of visits, et cetera, and 2) a top-down work plan. Some sales representatives indicate that their workplace is a car. There is a belief about the lack of one's desk and performing the work in a car or one's home. However, in my opinion, the car is not as much a workplace as it is a tool of work. It allows one to travel long distances, and thus allows one to work. Among the group of sales representa- 
tives performing their duties only outside the workplace and contacting the employer and colleagues only by phone or e-mail, the phenomenon of social alienation may occur. Such an employee is outside the "organizational life" of the workplace. In this group, as with remote workers from home, problems of alienation may arise. This may lead to a lower identification of the employee with the company or to psychological issues. Moreover, it is difficult for such an employee to estimate the real working time. Such a sales representative had to reevaluate their social role. Until now, a person has acted as an employee when they were at the workplace. Being an employee was thus referred to, among others, as the time spent in a given workplace. An individual in the role of a sales representative must function outside the workplace. The flexibility of the forms of employment, working in extra-dimensional working hours have caused the individual to perceive oneself as the self-employee. Such relocating of the role, overlapping of the role with other roles, such as the one of husband/wife, father/mother, may result in frustration and changes in the personality sphere.

The creation of conditions of relative freedom, independence, and decision-making also applies to the sales representative-superior relationship. Contacts with immediate superiors are limited due to the work system. The lack of frequent interactions and meetings with managers is perceived positively by the sales representatives. The communication of sales representatives and their immediate superiors is usually indirect. The interlocutors indicated that there was no possibility of direct, frequent communication with the main superiors due to, for example, the location of the company's headquarters outside Poland. In the branches located in Poland, the management policy of the main shareholder is implemented and thus the organizational culture is incorporated, including the ways of working and its organization. The informants emphasized that sometimes it happens in an inconsiderate way, without taking into account the specificity of Polish work and culture, which becomes a source of negative emotions.

Nobody is interested in the fact that sales are fewer in November. The plan is only slightly lower than in December. It's paranoia. They have Thanksgiving in November in the States, we have All Saints' Day here. People don't buy cosmetics from us then [laughs]. It has been raised many times, and the Americans are doing their job anyway. Do you believe that the plans [sales plans] arrive from the States! [man, 32-year-old, sales representative]

Interactions with superiors, as indicated by the informants, are a source of many emotions, including fellow feeling, trust, satisfaction, and admiration:

I hardly see the boss. He trusts me. I am in the field rather than on the ground here...If necessary, I'm mainly contacted by phone or e-mail. But, as I say, I trust him and he trusts me. This freedom suits me. [man, 31-year-old, sales representative]

and fear, stress, anger, and even mutual hostility:

We don't like each other; it's normal, very correct. She doesn't like me and I don't like her. Nobody likes her anyway. [man, 41-year-old, sales representative]

Sales representatives are often given free rein as to how they work. It is visible in the case of sales representatives working in small enterprises with Polish capital and employing one to three salespeople. The informants point to the pros and cons of such a situation. They praise situations when the boss 
does not interfere with what they do and how they work, but, at the same time, emphasize that they are often on their own. In the absence of a back office, they feel the burden of the decisions they make. According to sales representatives, personality traits play the greatest role in relations with the manager. Some managers are involved in their work to build a good atmosphere in the company. Such managers are open to the needs of their subordinates. Some managers prefer a system of reprimands, impose their management method, which makes it difficult to create informal relations between employees and to work in the company.

The boss is in Busko and I am here in Lodz with two colleagues. We settle accounts once a month. Then we go to the company's headquarters. And if in the meantime, there is a phone call that you have to arrive, you start to think about what happened, what is going on, what did you screw up. Then it may not be nice. But, such situations are rare. [man, 37-year-old, sales representative]

It should be noted that the interviewees, when talking about their relations with superiors, often did not mention their immediate superiors. There were narratives in which the interlocutors claimed that there was no boss, and when asked, they indicated that the boss was somewhere, but far away, and they rarely see him. When talking about their work, sales representatives most often pointed to interactions with the company they work for, and as such the company can be seen as a supervising unit. Thus, it can be concluded that interactions with superiors are not frequent and that they are horizontal in nature. The story about the superiors appeared in the context of the sales representatives' job evaluation. The fact that a manager was traveling with a sales representative all day following a certain "track" (in vivo code) and observing their actions while interacting with customers or driving a company car was indicated most frequently.

When you got in with this sales representative, the point was that he wouldn't make some nasty pranks while driving a car covered with company signs. Like forcing the right of way, behaving vulgarly, inelegantly, et cetera. He also had to present the company's culture, which was very important. [man, 52-year-old, former sales representative, manager]

In their statements, the interlocutors emphasized the freedom of action and "freedom" (in vivo code). Freedom is a symbol. It is a keyword that awakes the imagination, stimulates emotions, and, consequently, directs the intellect to actions following the expectations of the organization. Even if freedom is only apparent, the aspirations defined by this word were strongly internalized by the sales representatives.

What matters to me now is that I can make my own decisions...I have freedom. [man, 34-year-old, sales representative]

I feel so free in this job, at least I'm always somewhere else. [man, 26-year-old, sales representative]

It's cool about this job that I know how much I have to work to earn. If I don't feel like it, I can let it go. One day more, the next less. And contact with people. [man, 37-year-old, sales representative]

Freedom is also a motivator for effective work, including working with emotions. It is an important factor in the modern labor market.

If someone offered me a job for more money, but I would have to give up the freedom I have here, 
for example, if I could not plan for myself every next working day, I probably wouldn't take it. [man, 43-year-old, sales representative]

Today, traditional incentives such as high wages, bonuses, and promotion opportunities are no longer sufficient. Employees expect a flexible working day, the ability to manage their working time, tasks that are challenging, but, at the same time, that do not require maximum dedication. There are a lot of discussions about work-life balance. For the informants, as well as the entire $\mathrm{Y}$ and $\mathrm{Z}$ generations (see: Giddens 2006; Rogozińska-Pawełczyk 2014; Wiktorowicz and Warwas 2016), it is important to feel freedom understood as freedom of working time, freedom of speech, tolerance, and an orientation towards diversity and individualism. In a given organization, generation $\mathrm{Y}$ expects an atmosphere of uniqueness and importance of the goals pursued. They value partnership relations between the employee and the supervisor. All this enables them to work as a sales representative

We all call each other by name. We often go to various training courses and that's probably why. My boss? I've called him Jack for a long time. Anyway, we've known each other for so many years. [man, 34-yearold, sales representative]

\section{Interactions with Colleagues}

The last group of factors described in this article and influencing working with emotions in the case of sales representatives concerns the relationship between a sales representative and their colleagues. In most cases, those are positive relationships that evoke fellow feelings and even friendship. They are based on the emotions of trust, mutual respect, satisfaction, as well as on help and support, although, as the interviewees emphasize, in some organizations, contacts with other sales representatives are limited to accidental meetings in hotels during overnight work, the so-called "business and social contacts during the tour" (in vivo code) and meetings during various types of organizational rituals, including training. What seems to be most frequent in interactions between colleagues was loyalty.

In my company there work young people aged 20 to 40. They are very cool and we meet a lot after work. There is no envy among us. We try to help and support each other. [woman, 26-years-old, sales representative]

I keep in touch with many people. They are my friends. Those are the people I can meet for a BBQ with a glass of beer and chat. [man, 37-years-old, sales representative]

Contacts at work, although limited, are extended to the non-professional sphere, resulting in many years of friendships:

such a friendly trip, because it was not organized at all. Three friends from the company. We left, took a boat, borrowed a sailboat, swam on the lakes, fished, drank beer, talked about everything...But, with such complete ease...Usually, after our trip, which was no secret in the company, it was known that we were leaving, and Marysia came to us and said, "Well, I heard that you are going, when you are going, remember to take a camera and write me 10 sentences" [photos and information about the trip were published in the company's newsletter]. [man, 52-year-old, former sales representative, manager]

Although sales representatives help each other and support each other on the road, while staying in 
different hotels, they rarely talk about situations directly related to their business activities.

But, no one revealed their secrets. No one is to sell some cool information. [man, 34-year-old, sales representative]

Competition is the factor that differentiates sales representatives due to the nature of interactions. Some respondents point to its destructive nature. In particular, older sales representatives emphasized the lack of mutual understanding and trust.

Very good, I like everyone very much and everyone likes me uhm and it all looks very nice. It's nice, nice, but there is always a hidden agenda. It turns out that sales representatives are like wolves. One looks at the other as a victim, as if he were just to steal X's company, trick him, use him, and leave him. Well, that's what sales representatives are. [man, 44-year-old, sales representative]

Competition is also an incentive to work more intensively. Many interviewees indicated competition as a factor that directly or indirectly influenced the level of sales and the achievement of the assumed goals:

this work always gives some satisfaction. There is always some rivalry between us here in the region, always if we meet, we know who sold the most, who was the best in this and that, if I am the best in a certain period, there is always such a moment of satisfaction and further motivation for this work and, and actions. [man, 27-year-old, sales representative]

The rivalry is very big, the rivalry exists, of course, nobody wants to be the worst. First of all, it's the basic thing, but it has such a positive dimension. It motivates to action. [man, 30-year-old, sales representative]

Competition is an important motivational factor and contributes to deep emotional work. For managing employees' emotions, it is an important method of action, leading to satisfaction, pride, as well as increasing employees' identification with the organization to which they belong. Many interviewees emphasized pride in their individual or team achievements, referring to the implementation of the sales plan assumed by the organization and obtaining material benefits as a result.

There is a ranking of the best results and...the top 15 people who achieved the best results go on a trip. This year they were on the Caribbean islands. I can proudly say that I was one of them. Next year it will be a trip to Colorado in the United States. It's a lot of fun. You have to try it. [woman, 26-year-old, sales representative, office supplies]

The competitions were amazing. It was amazing. And it motivated people a lot. Every month, those results were presented in the newsletter and were announced, the heads of the regions were emailed... and each boss...was obliged to provide that data to employees. Hear up, your region...is second. We have to try...Such turning on, charging of the batteries. [man, 52-year-old, former sales representative, manager]

The competition allows for activities in which social actors can reflect on themselves (see: Strauss 1959). The activities of sales representatives taking place within a group context are relational in nature and are produced in the process of mutual communication and negotiation of meanings (see: Strauss 1959; 1993). It is this level of activity that directly influenc- 
es both the interactions with other colleagues and the emotions aroused in the process. It controls the emotional work, directing it to deep activities desired by a given organization.

\section{Conclusion}

This paper aimed to show four factors influencing and shaping interactions undertaken by sales representatives in the context of their work with emotions. Adapting the perspective of symbolic interactionism, I indicated the mutual nature of interactions and, as a result, the formation and management of emotions. I emphasized the two-way nature of the interaction by referring to the negotiation of meanings and the interpretation of gestures. Contrary to other sociological concepts, symbolic interactionism emphasizes the communication processes in an organization, relations between organizational positions, including relations between the identities of organizational actors, and organizational and organizing activities (see: Konecki 2007:8-9). Social reality, as emerging in the course of interactions, is fluid. All social structures arise in the process, in action (see: Strauss 1993).

The sales representatives in this study are mainly young people for whom satisfying the needs such as owning an apartment, a car, wearing high-end clothes is vital. In the interviews, they emphasized that the work of a sales representative is associated with frequent trips and staying away from home for a long time, therefore, it is more suitable for younger people, who did not yet start a family. Singles find it much easier to work in rapidly changing conditions, requiring constant availability and mobility. Sales representatives remaining in relationships must count on the understanding of partners and their trust.
As a result of much training and organizational indoctrination, sales representatives quickly learn how to build a relationship with the customer, including surface emotional work. They know which emotions are desired by the organization and it is a condition of obtaining maximum benefits and profits. By building lasting relationships with the client, they replace surface actions with deep ones. Activities based on deep emotional work not only allow them to pursue their professional goals, including achieving a specific profit, but also shape the direction and nature of the interactions undertaken by negotiating, defining, and giving meanings to objects in their social reality. Interactions are a platform for sales representatives' activities. They have a different direction and character. They are a source of emotions, but also a platform for negotiating meanings, including emotions. The sales representatives' goal is to build trust between them and the customer. This can be done either due to surface action-giving the impression of a patient and serious person, or in the course of deep action, as a result of which a person becomes more patient and serious, and thus no longer has to "make an impression" (Hochschild 2009:159).

It should be noted that the ways of dealing with emotions among sales representatives are a derivative of the perspective they adopt regarding the nature of their work. They are the result of the work performed by the sales representatives during the training. They are intended and learned activities. Due to participation in initial training, even novice sales representatives quickly develop strategies to deal with positive and negative emotions, which they effectively manage.

The main research technique was unstructured and in-depth interviews in the case of which we are 
dealing with someone's experiences. This time the data were primarily made of the stories about the work of sales representatives. In their narratives, they shared information regarding emotions both desired and felt in their profession. More than once, the interviewees revealed the process of working with emotions, unconsciously pointing to surface or deep emotional work. They talked about "saving face," which allows them to control their emotions, but also their clients, as well as pointed to the moment when surface actions turned into deep oneswhen, for example, due to constant interactions, they started to genuinely like the client and could no longer be cross with them. They talked about becoming more patient and understanding. Of course, as researchers, we can never be certain to what extent the story told by the interlocutors indeed re-

\section{References}

Adler, Patricia A. and Peter Adler. 1987. Membership Roles in Field Research. Newbury Park, CA: Sage.

Becker, Howard S. and Blanche Greer. 1960. "Participant Observation. The Analysis of Qualitative Field Data." Pp. 267-288 in Human Organization Research. Field Relations and Techniques, edited by R. Adams and J. Preiss. Homewood, IL: Dorsey.

Blumer, Herbert. 2007. Interakcjonizm symboliczny. Perspektywa $i$ metoda [Symbolic Interactionism. Perspective and Method]. Cracow: Nomos.

Brotheridge, Celeste M. and Alicia A. Grandey. 2002. “Emotional Labor and Burnout: Comparing Two Perspectives of 'People Work.'” Journal of Vocational Behavior 60:17-39.

Deegan, Mary Jo. 2001. "The Chicago School of Ethnography." Pp. 11-25 in Handbook of Ethnography, edited by P. Atkinson et al. Thousand Oaks, CA: Sage.

Denzin, Norman K. 1978. The Research Act: A Theoretical Introduction to Sociological Methods. New York: McGraw-Hill. flects their experiences. The same goes for examining emotions. Therefore, in this study, I also relied on observations - to contextualize the data collected due to conducting interviews.

The activities of sales representatives presented in the article referred to working conditions, interactions with their superiors and colleagues, and, importantly, interactions with customers. In the context of working with emotions, the situation of sales representatives may not be significantly different from other professions, especially in terms of relations with superiors. Thus, I hope that this article will contribute to a wider interest in working with emotions and encourage other researchers to do studies in this area among representatives of other professions.

Dzięcielska-Machnikowska, Stefania. 1990. “Socjologia pracy i przemysłu [The Sociology of Work and Industry]." Pp. 257278 in Socjologia polska [Polish Sociology], edited by Z. Krawczyk. Warsaw: Wydawnictwo Uniwersytetu Warszawskiego.

Fukuyama, Francis. 1997. Ostatni człowiek [The End of History and the Last Man]. Poznan: Wydawnictwo Zysk i S-ka.

Giddens, Anthony. 2006. Socjologia [Sociology]. Warsaw: Wydawnictwo Naukowe PWN.

Goleman, Daniel. 1997. Inteligencja emocjonalna [Emotional Intelligence]. Poznan: Media Rodzina of Poznań.

Grandey, Alicia A. 2000. "Emotional Regulation in the Workplace: A New Way to Conceptualize Emotional Labor." Journal of Occupational Health Psychology 5(1):95-110.

Gross, James J. 1998. “Antecedent- and Response-Focused Emotion Regulation: Divergent Consequences for Experience, Expression, and Physiology." Journal of Personality and Social Psychology 74(1):224-237. 
Hammersley, Martyn and Paul Atkinson. 2000. Metody badań terenowych [Ethnography. Principles in Practice]. Poznan: Wydawnictwo Zysk i S-ka.

Hammersley, Martyn and Paul Atkinson. 2007. Ethnography. Principles in Practice. New York: Taylor and Francis.

Hochschild, Arlie R. 1983. The Managed Heart: Commercialization of Human Feeling. Berkeley, CA: University of California Press.

Hochschild, Arlie R. 2009. Zarzadzanie emocjami. Komercjalizacja ludzkich uczuć [The Managed Heart: Commercialization of Human Feeling]. Warsaw: Wydawnictwo Naukowe PWN.

Hughes, Everett C. 1958. Men and Their Work. Glencoe, IL: Free Press.

Johnson, Hazel-Anne M. and Paul E. Spector. 2007. “Service with a Smile: Do Emotional Intelligence, Gender and Autonomy Moderate the Emotional Labor Process?" Journal of Occupational Health Psychology 12(4):319-333.

Kanter, Rosabeth Moss. 1977. Men and Women of the Corporation. New York: Basic Books.

Kemper, Theodore D. 2005. “Modele społeczne w wyjaśnianiu emocji [Social Models in Explaining Emotions]." Pp. 72-87 in Psychologia emocji [Psychology of Emotions], edited by M. Lewis and J. M. Haviland-Jones. Gdansk: Gdańskie Wydawnictwo Psychologiczne.

Kemper, Theodore D. 2008. "Power, Status, and Emotions." Pp. 369-383 in Emotions. A Social Science Reader, edited by M. Greco and P. Stenner. London, New York: Routledge Taylor and Francis Group.

Kempny, Danuta. 2008. Obstuga logistyczna [Logistic Service]. Katowice: Wydawnictwo Akademii Ekonomicznej w Katowicach.

Konecki, Krzysztof T. 1988. "Praca w koncepcji socjologii interakcjonistycznej [Work in the Lens of Interactionist Sociology]." Studia Socjologiczne 1(108):225-245.

Konecki, Krzysztof T. 2000. Studia z metodologii badań jakościowych. Teoria ugruntowana [Studies in Qualitative Research Methodology. Grounded Theory]. Warsaw: Wydawnictwo Naukowe PWN.

Konecki, Krzysztof T. 2007. "Procesualne ujęcie organizacji. Organizacje, struktury, procesy i tożsamości [Processual Approach to the Organization. Organizations, Structures, Processes, and Identities]." Pp. 7-21 in Zarzadzanie organizacjami. Organizacja jako proces [Organization Management. Organization as a Process], edited by K. T. Konecki and P. Chomczyński. Lodz: Wydawnictwo Uniwersytetu Łódzkiego.

Kopertyńska, Wanda M. 2009. Motywowanie pracowników. Teoria i praktyka [Motivating Employees. Theory and Practice]. Warsaw: Agencja Wydawnicza Placet.

Kostera, Monika. 2003. Antropologia organizacji. Metodologia badań terenowych [Organization Anthropology. Field Research Methodology]. Warsaw: Wydawnictwo Naukowe PWN.

Kostera, Monika, ed. 2011. Etnografia organizacji. Badania polskich firm i instytucji [Organizational Ethnography. Studies of Polish Companies and Institutions]. Gdansk: Gdańskie Wydawnictwo Psychologiczne.

Kostera, Monika. 2012. “Etnografia organizacji [Organizational Ethnography]." Pp. 73-77 in Stownik Socjologii Jakościowej [Dictionary of Qualitative Sociology], edited by K. Konecki and P. Chomczyński. Warsaw: Difin.

Kulpińska, Jolanta. 1986. “Tendencja rozwoju socjologii pracy [Development Tendency of the Sociology of Work]." Pp. 8-25 in Socjologia pracy i przemystu [The Sociology of Work and Industry], edited by S. Dzięcielska-Machnikowska and J. Kulpińska. Lodz: Wydawnictwo Uniwersytetu Łódzkiego.

Kvale, Steinar. 2004. InterViews. Wprowadzenie do jakościowego wywiadu badawczego [InterViews. An Introduction to Qualitative Research Interviewing]. Bialystok: Trans Humana.

Lee, Raymond T. and Céleste M. Brotheridge. 2011. “Words from the Heart Speak to the Heart: A Study of Deep Acting, Faking, and Hiding among Child Care Workers." The Career Development International 16(4):401-420.

Lis, Franciszek J. 1982. Człowiek w procesie pracy. Praca chęć czy przymus? [Man in the Process of Work. Work-Will or Compulsion?]. Warsaw: Instytut Wydawniczy Związków Zawodowych.

Lutyński, Jan. 1968. “Ankieta i jej rodzaje na tle podziału technik otrzymywania materiałów [Questionnaire and Its Types and the Division of Data Collection Techniques]." Pp.10-56 in Analizy i próby technik badawczych w socjologii, Tom 2 [Analyzes and Trials of Research Techniques in Sociology, Vol. 2], edited by Z. Gostkowski and J. Lutyński. Wroclaw: Zakład Narodowy im. Ossolińskich.

Lutyński, Jan. 1994. Metody badań społecznych. Wybrane zagadnienia [Social Research Methods. Selected Issues]. Lodz: Łódzkie Towarzystwo Naukowe. 
Mayo, Andrew. 2002. Kształtowanie strategii szkoleń i rozwoju [Creating a Learning and Development Strategy]. Cracow: Oficyna Ekonomiczna.

Meanwell, Emily, Joseph D. Wolfe, and Tim Hallet 2008. “Old Paths and New Directions: Studying Emotions in the Workplace." Sociology Compass 2:537-559.

Nelson, E. D. (Adie) and Ronald D. Lambert. 2001. "Sticks, Stones and Semantics: The Ivory Tower Bully's Vocabulary of Motives." Qualitative Sociology 24(1):83-106.

Pawłowska, Beata. 2013. Emocje społeczne w pracy nauczyciela i przedstawiciela handlowego [Social Emotions in the Work of Teachers and Sales Representatives]. Lodz: Wydawnictwo Uniwersytetu Łódzkiego.

Pawłowska, Beata. 2020. "Pride in Teachers' Everyday Work. Conditions and Contexts." Qualitative Sociology Review 16(1):28-48.

Pierce, Jennifer L. 1999. "Emotional Labor among Paralegals.” The Annals of the American Academy of Political and Social Science 561:127-142.

Prus, Robert. 1989. Making Sales: Influence as Interpersonal Accomplishment. Newbury Park, CA: Sage.

Prus, Robert. 1994. "Consumers as Targets: Autonomy, Accountability, and Anticipation of the Influence Process." Qualitative Sociology 17(3):243-262.

Prus, Robert. 1997. Subcultural Mosaics and Intersubjective Realities. An Ethnographic Research Agenda for Pragmatizing the Social Sciences. New York: State University of New York Press.

Prus, Robert and Scott Grills. 2003. The Deviant Mystique: Involvements, Realities and Regulation. Westport, CT: Praeger.

Przybyłowska, Ilona. 1978. “Wywiad swobodny ze standaryzowaną listą poszukiwanych informacji i możliwości jego zastosowania w badaniach socjologicznych [Interview with a Standardized List of Questions and the Possibility of Its Application in Sociological Research]." Przegląd Socjologiczny 30:54-68.

Rafaeli, Anat and Robert I. Sutton. 1990. "Busy Stores and Demanding Customers: How Do They Affect the Display of Positive Emotion?" Academy of Management Journal 33:623-637.

Raz, Aviad. 2003. "The Slanted Smile Factory: Emotion Management in Tokyo Disneyland." Pp. 210-227 in The Cultural
Study of Work, edited by D. Harper and H. M. Lawson. Lanham, MD: Rowman \& Littlefield.

Rogalin, Christabel L. and Laura E. Hirshfield. 2013. “Emotion and Leadership: What Scholarship on Status and Identity Can Tell Us." Sociology Compass 7/6:487-501.

Rogozińska-Pawełczyk, Anna. 2014. Pokolenia na rynku pracy [Generations on the Labor Market]. Lodz: Wydawnictwo Uniwersytetu Łódzkiego.

Scheff, Thomas J. 1988. "Shame and Conformity: The Deference Emotion System." American Sociological Review 53:395-406.

Scheff, Thomas J. 1990. Microsociology. Discourse, Emotion, and Social Structure. Chicago: University of Chicago Press.

Scheff, Thomas J. 2000. "Shame and the Social Bond: A Sociological Theory." Sociological Theory 18(1):84-99.

Scheff, Thomas J. 2003. "Shame and Self in Society." Symbolic Interaction 26:239-262.

Schwartz, Morris and Charlotte G. Schwartz. 1955. "Problems in Participant Observation." American Journal of Sociology 60(4):343-353.

Schweingruber, David and Nancy Berns. 2003. “Doing Money Work in a Door-to-Door Sales Organization." Symbolic Interaction 26(3):447-471.

Shott, Susan. 1979. "Emotion and Social Life: A Symbolic Interactionist Analysis." American Journal of Sociology 84:1317-1334.

Silverman, David. 2007. Interpretacja danych jakościowych [Interpreting Qualitative Data]. Warsaw: Wydawnictwo Naukowe PWN.

Smith, Allen C. and Sherryl Kleinman. 1989. "Managing Emotions in Medical School: Student's Contacts with the Living and the Dead." Social Psychology Quarterly 52:56-69.

Springer, Agnieszka and Karolina Oleksa. 2017. “Praca emocjonalna a wypalenie zawodowe - Analiza porównawcza pracy nauczycieli i pracowników sektora usług komercyjnych [Emotional Work and Burnout. A Comparative Analysis of the Work of Teachers and Employees in the Commercial Services Sector]." Medycyna Pracy 68(5):605-615.

Strauss, Anselm L. 1959. Mirrors and Masks. The Search for Identity. Glencoe, IL: Free Press. 
Strauss, Anselm L. 1988. "The Articulation of Project Work: An Organizational Process." Sociological Quarterly 29:163178.

Strauss, Anselm L. 1993. Continual Permutations of Action. New York: Aldine de Gruyter.

Sutton, Robert I. 1991. "Maintaining Norms about Expressed Emotion: The Case of Bill Collectors." Administrative Science Quarterly 36:245-268.

Sykes, Gresham and David Matza. 1979. "Techniques of Neutralization: A Theory of Delinquency." Pp. 497-504 in Social Interaction. Introductory Readings in Sociology, edited by H. Robboy, S. Greenblatt, and C. Clark. New York: St. Martin Press.

Szczepański, Jan. 1961. "Uwagi o przedmiocie i zadaniach socjologii [Notes on the Subject and Tasks of Sociology]." Pp. 169-184 in Jak pracuje człowiek [How Man Works], edited by B. Biegeleisen-Żelazowski et al. Warsaw: Książka i Wiedza.

Szczygieł, Dorota et al. 2009. "Praca emocjonalna w zawodach usługowych - pojęcie, przegląd teorii i badań [Emo- tional Work in Service Occupations-Concept, Review of Theory and Research]." Psychologia Społeczna 3(11):155-166.

Wharton, Amy S. 2009. "The Sociology of Emotional Labor." Annual Review of Sociology 35:147165.

Wiktorowicz, Justyna and Izabela Warwas. 2016. "Pokolenia na rynku pracy [Generations on the Labor Market]." Pp. 19-37 in Pokolenia - co się zmienia? Kompendium zarządzania międzygeneracyjnego [Generations-What Is Changing? Compendium of Intergenerational Management], edited by J. Wiktorowicz et al. Warsaw: Wolters Kluwer S.A.

Williams, Christine L. 2006. Inside Toyland: Working, Shopping, and Social Inequality. Berkeley, CA: University of California Press.

Williams, Lisa A. and David DeSteno. 2008. "Pride and Perseverance: The Motivational Role of Pride." Journal of Personality and Social Psychology 94(6):1007-1017.

Wojciechowska, Magdalena. 2018. "Doing Research on Behindthe-Scenes Phenomena: Entering the Female Escort Industry." Pp. 133-139 in The Craft of Qualitative Research, edited by S. Kleinknecht, L-J. K. van den Scott, and C. Sanders. Toronto: Canadian Scholars' Press.

\section{Citation}

Pawłowska, Beata. 2020. "The Work of Sales Representatives in the Context of Interactions and Work with Emotions." Qualitative Sociology Review 16(4):64-88. Retrieved Month, Year (http://www.qualitativesociologyreview.org/ENG/archive_eng.php). DOI: http://dx.doi.org/10.18778/1733-8077.16.4.05 